\title{
PENGELOLAAN KELAS OLEH GURU BAHASA JEPANG DI KELAS XI IPB SMA WIRABHAKTI SINGARAJA DALAM PEMBEAJARAN BAHASA JEPANG TAHUN PELAJARAN 2018/2019
}

\author{
L.P.K.Sageningsih, G.S.Hermawan, D.M.S.Mardani \\ Program Studi Pendidikan Bahasa Jepang, \\ Universitas Pendidikan Ganesha \\ Singaraja \\ e-mail: kurniasageningsih@gmail.com \\ satya.hermawan@undiksha.ac.id desak.mardani@undiksha.ac.id
}

\begin{abstract}
Abstrak
Penelitian ini bertujuan untuk mendeskripsikan bagaimana pengelolaan kelas yang dilakukan oleh guru bahasa Jepang di kelas IX IPB SMA Wirabhakti Singaraja dalam pembelajaran bahasa Jepang. Data hasil penelitian akan dianalisis menggunakan metode deskriptif kualitatif. Subjek penelitian ini adalah guru bahasa Jepang di SMA Wirabhakti Singaraja. Pengumpulan data dilakukan dengan metode observasi, wawancara, dan dokumentasi. Hasil penelitian menunjukkan bahwa guru bahasa Jepang di SMA Wirabhakti Singaraja sudah melakukan pengelolaan kelas dengan baik. Guru melakukan pengelolaan kelas dengan menerapkan pendekatanpendekatan dalam pengelolaan kelas, prinsip-prinsip pengelolaan kelas, dan komponen-komponen keterampilan pengelolaan kelas. Dalam melakukan pengelolaan kelas guru tidak menggunakan pendekatan ancaman dan pendekatan resep serta prinsip keluwesan. Hal tersebut dikarenakan tingkah laku siswa di kelas masih bisa diatasi dengan baik oleh guru. Selain itu untuk mereaksi tingkah laku siswa disesuaikan dengan keadaan yang terjadi di kelas.
\end{abstract}

Kata kunci : Pendekatan, prinsip, komponen

\section{要旨}

本研究の目的は、ウィラバクティシンガラジャ高校の XI IPB クラスの日本語教師が 日本語学習において教室管理をどのように実施するかを説明することを目的としてい る。研究データは、定性的記述方法を使用して分析される。研究の対象は、ウィラバ クティシンガラジャ高校の日本語教師だった。データ収集は、観察、インタビュー、 および文書化の方法によって行われる。その結果は、ウィラバクティシンガラジャ高 校の日本語教師が教室をうまく管理していたことがわかった。教師は、教室管理、ク ラス管理の原則、および教室管理スキルの要素にアプローチを適用することにより、 教室管理を実施する。教室の管理では、教師は务威アプローチ、レシピアプローチ、 柔軟性の原則を使用しない。これは、クラスの生徒の行動が教師によって依然として 適切に処理されるためだ。応答するために行われるアクション生徒の行動は、クラス で発生する状況に合わせて調整される。

キーワード : アプローチ、原則、要素 


\section{Pendahuluan}

Guru sebagai tenaga pendidik memiliki peranan terpenting dalam proses pembelajaran di sekolah. Itu dikarenakan guru memiliki tugas utama yaitu mengajar, membimbing, mengarahkan, menilai, dan mengevaluasi peserta didik untuk mencapai tujuan pembelajaran. Tugas utama tersebut harus dijalankan sebaik mungkin oleh guru dengan berlandaskan pada kompetensi tertentu.

Menurut Undang-Undang no 14 tahun 2005 kompetensi tersebut yaitu kompetensi profesional, kompetensi pedagogik, kompetensi kepribadian, dan kompetensi sosial. Oleh karena itu keempat kompetensi tersebut sangat penting dimiliki oleh guru sebagai bekal untuk melaksanakan proses pembelajaran guna mencapai keberhasilan tujuan pembelajaran.

Pengelolaan kelas merupakan salah satu dari beberapa keterampilan dalam kompetensi profesional yang harus dimiliki guru. Menurut Sumantri \& Permana (1998:281) menyatakan bahwa "keterampilan mengelola kelas merupakan kemampuan guru dalam mewujudkan dan mempertahankan suasana belajar mengajar yang optimal". Selanjutnya Djamarah \& Zain (2006:174) menjelaskan bahwa "pengelolaan kelas dimaksudkan untuk menciptakan lingkungan belajar yang kondusif bagi anak didik sehingga tercapai tujuan pengajaran secara efektif dan efisien".

Pelaksanaan proses pembelajaran dalam rangka mencapai tujuan pembelajaran tidak hanya ditentukan oleh faktor-faktor yang berhubungan dengan proses pembelajaran saja. Misalnya dalam menguasai materi, pemilihan metode yang tepat, penggunaan sarana, dan evaluasi yang tepat. Hal lain yang tidak kalah penting yaitu mencegah perilaku siswa yang mengganggu jalannya proses pembelajaran. Sehingga guru harus memiliki keterampilan pengelolaan kelas untuk membantu guru mengontrol atau mengatur perilaku siswa sehingga proses pembelajaran yang diharapkan guru dapat berjalan dengan baik.

Rohani (2004:123) menyatakan pengelolaan kelas dan pembelajaran adalah dua kegiatan yang sangat erat hubungannya namun dapat dan harus dibedakan satu sama lain karena tujuannya berbeda. Pembelajaran mencangkup semua kegiatan yang secara langsung dimaksudkan untuk mencapai tujuan-tujuan khusus pembelajaran. Pengelolaan kelas menunjukkan kepada kegiatan-kegiatan yang menciptakan dan mempertahankan kondisi yang optimal bagi terjadinya proses belajar mengajar.

Guru harus melakukan pengelolaan kelas yang baik untuk dapat menciptakan kondisi belajar yang kondusif. "Seorang guru yang terampil mengelola kelas akan dapat menciptakan suasana pembelajaran yang kondusif, dan guru tersebut akan mampu mengendalikan kelas jika terjadi gangguan dalam proses pembelajaran" (Sani, 2019:262). Kelas yang tidak kondusif membuat situasi pembelajaran tidak efektif dan tidak menyenangkan. Alhasil membuat siswa tidak bisa maksimal dalam memahami materi pembelajaran, selain itu guru juga akan mengalami kesulitan dalam menyampaikan materi pelajaran.

Beberapa faktor pemicu kelas menjadi kurang kondusif yaitu siswa ribut dan tidak fokus saat guru sedang menjelaskan materi pelajaran. Terdapat siswa hiperaktif yang suka mengganggu temannya yang lain. Guru yang kurang tegas sehingga siswa tidak mau 
mengikuti instruksi guru. Siswa yang mulai kelelahan pada jam-jam terakhir. Serta jumlah siswa yang banyak sedangkan ruang kelas tidak cukup luas.

Guru yang dapat menjaga kelasnya tetap kondusif akan membuat siswa merasa nyaman mengikuti kegiatan belajar di kelas. Selain itu kelas yang kondusif dapat merangsang dan menantang siswa untuk belajar. Sehingga dalam hal ini sebagai pengelola kelas yang baik guru berperan dalam memberikan dan menciptakan suasana atau keadaan belajar yang memungkinkan siswa dapat belajar dengan nyaman.

Langkah-langkah yang harus dilakukan oleh guru agar mampu menguasai dan mengelola kelas dengan baik, yaitu 1) Persiapan yang cermat, yang dimaksud persiapan yang cermat di sini adalah guru harus mengenali benar siswanya karena mereka memliki kemampuan yang berbeda-beda, 2) Tetap menjaga dan terus mengembangkan rutinitas agar siswa tidak selalu dibingungkan dengan gaya dan model penugasan yang terus berubah, tidak ada salahnya guru menjaga rutinitas. Kecepatan siswa memahami apa yang akan dilakukan gurunya, akan mampu mengurangi keributan di kelas, 3) Bersikap tenang dan terus percaya diri. Dengan ketenangan dan kepercayaan diri yang tinggi, guru akan mampu mengendalikan siswa-siswanya, sehingga proses pembelajaran akan berjalan sesuai dengan apa yang diharapkan, karena dengan bersikap tenang dan percaya diri, guru tidak akan mudah panik dan kehilangan keseimbangan, serta tidak akan ragu ketika menghadapi siswa-siswanya, 4) Bertindak dan bersikap professional, seharusnya seorang guru harus bertindak dan bersikap profesional yang tidak hanya mampu melaksanakan tugas pokoknya, namun juga mampu melaksanakan hal-hal yang terkait dengan keberhasilan tugas pokok tersebut, 5) Mampu mengenali perilaku yang tidak tepat. Dalam hal ini guru harus mampu mengenali perilaku tidak tepat dari siswa-siswanya, yakni dalam bentuk apa perilakunya, kapan akan muncul, dan apakah perilaku tersebut sudah memerlukan respon dari guru atau belum.

Berdasarkan hasil observasi awal yang dilakukan pada tanggal 25 Oktober 2018 di kelas XI IPB SMA Wirabhakti Singaraja, terdapat permasalahan yang muncul ketika guru melakukan pengelolaan kelas yaitu kurangnya perhatian siswa dalam proses pembelajaran. $\mathrm{Hal}$ ini terlihat ketika guru menjelaskan materi pelajaran siswa sibuk sendiri-sendiri dan asyik mengobrol dengan teman sebangkunya. Selain itu suasana kegiatan belajar kurang menarik, tampak beberapa siswa yang ribut saat guru menyampaikan materi pelajaran. Siswa juga kurang bersemangat mengikuti kegiatan pembelajaran. Terlihat saat guru menjelaskan materi pelajaran siswa tidur di kelas. Dari permasalahan tersebut, guru harus mengatasainya dengan baik. Jika tidak diatasi dengan baik maka kondisi kelas tidak lagi kondusif. Tentu saja akan mengganggu jalannya proses pembelajaran. Hal ini nantinya akan berdampak pada tujuan pembelajaran yang diharapkan guru tidak tercapai.

Penelitian tentang pengelolaan kelas pernah dilakukan oleh Riadi (2018). Hasil penelitian menunjukkan pengelolaan kelas yang efektif merupakan persyaratan mutlak terwujudnya pembelajaran yang efektif dan optimal. Keterampilan guru dalam mengelola kelas secara signifikan mempengaruhi situasi dan kondisi pembelajaran di dalam kelas. Dalam mengelola kelas guru menggunakan berbagai pendekatan, prinsip-prinsip, dan komponen-komponen pengelolaan kelas untuk menciptakan dan memelihara kondisi belajar yang optimal. Pendekatan resep (cook book), keluwesan, penekanan pada hal-hal yang Jurnal Pendidikan Bahasa Jepang | 347 
positif, dan menemukan serta memecahkan tingkah laku yang menimbulkan masalah tidak dilakukan oleh guru. Penataan ruang kelas dilakukan guru dengan cara disesuaikan dengan pembelajaran dan/atau atas seizin dari sekolah.

Dari apa yang telah dipaparkan, maka perlu dilakukan penelitian yang berjudul "Pengelolaan Kelas oleh Guru Bahasa Jepang di Kelas XI IPB SMA Wirabhakti Singaraja dalam Pembelajaran Bahasa Jepang".

Adapun teori yang digunakan dalam penelitian ini yaitu (1) pengelolaan kelas, (2) tujuan pengelolaan kelas, (3) prinsip-prinsip pengelolaan kelas, (4) komponen-komponen keterampilan pengelolaan kelas, (5) masalah pengelolaan kelas. Teori pengelolaan kelas digunakan untuk menganalisis data yang berkaitan dengan pengelolaan kelas oleh guru bahasa Jepang di kelas XI IPB SMA Wirabhakti Singaraja dalam pembelajaran bahasa Jepang.

\section{Metode}

Penelitian ini mengangkat tentang pengelolaan kelas oleh guru bahasa Jepang di kelas XI IPB SMA Wirabhakti dalam pembelajaran bahasa Jepang. Pendekatan yang digunakan dalam penelitian ini adalah kualitatif. Pendekatan kualitatif dipilih untuk mendeskripsikan pengelolaan kelas yang dilakukan guru bahasa Jepang di kelas XI IPB SMA Wirabhakti dalam pembelajaran bahasa Jepang. Subjek dari penelitian ini adalah guru bahasa Jepang di SMA Wirabhakti Singaraja. Sedangkan objek dalam penelitian ini adalah pengelolaan kelas guru bahasa Jepang di kelas XI IPB SMA Wirabhakti Singaraja.

Metode pengumpulan data yang digunakan terdiri dari metode observasi, metode wawancara dan metode dokumentasi. Selanjutnya data hasil penelitian yang diperoleh akan dianalisis menggunakan teknik analisi data yaitu reduksi data, penyajian data dan penarikan simpulan.

\section{Hasil dan Pembahasan}

Berdasarkan hasil observasi pada tanggal 27 April 2019, 02 Mei 2019, 04 Mei 2019, 09 Mei 2019 dan 16 Mei 2019 di kelas XI IPB SMA Wirabhakti Singaraja, bahwa guru sudah melakukan pengelolaan kelas dengan baik. Pengelolaan kelas dilakukan dengan menerapkan pendekatan dalam pengelolaan kelas, prinsip-prinsip pengelolaan kelas dan komponen-komponen pengelolaan kelas untuk menciptakan kondisi belajar yang optimal.

Pada pendekatan pengelolaan kelas guru menggunakan berbagai pendekatan seperti pendekatan kekuasaan, pendekatan kebebasan, pendekatan pengajaran, pendekatan perubahan tingkah laku, pendekatan suasan emosi dan hubungan sosial, dan pendekatan elektis dan pluralistik.

Selain pendekatan pengelolaan kelas dan prinsip pengelolaan kelas guru menerapkan komponen-komponen pengelolaan kelas. Komponen-komponen pengelolaan kelas dibagi menjadi dua bagian, yaitu keterampilan yang berhubungan dengan penciptaan dan pemeliharaan kondisi belajar yang optimal dan keterampilan yang berhubungan dengan pengembangan kondisi belajar yang optimal. Pada bagian keterampilan yang berhubungan dengan penciptaan dan pemeliharaan kondisi belajar yang optimal meliputi sikap tanggap, membagi perhatian. Sedangkan keterampilan yang berhubungan dengan pengembangan kondisi belajar yang optimal hanya meliputi modifikasi tingkah laku. Berikut hasil dari Pengelolaan Kelas yang dilakukan oleh Guru Bahasa Jepang di Kelas XI IPB SMA Wirabhakti Singaraja dalam pembelajaran bahasa Jepang. 
Pada pendekatan kekuasaan, untuk mendisiplinkan atau mengatur tingkah laku siswa, guru melakukan pendekatan kekuasaan. Contoh pendekatan kekuasaaan yang dilakukan guru ketika guru menjelaskan kosakata ada siswa yang tidak memperhatikan guru, kemudian guru menegur siswa tersebut dengan berkata "Coba perhatikan ke depan dulu", "Ayo perhatikan dulu". Guru juga menegur siswa ketika guru sedang menjelaskan pola kalimat ada siswa yang tidak memperhatikan guru, kemudian guru menegur dengan berkata "Perhatikan dulu ya, jangan lain-lain". Dalam hal ini guru menegur siswa untuk memusatkan perhatian siswa dengan memfokuskan pandangan siswa ke depan sehingga siswa memperhatikan materi yang diajarkan guru.

Selain itu guru memberikan perintah kepada siswa ketika ada salah satu siswa yang belum membuat contoh kalimat yang sudah dijelaskan guru. Perintah tersebut berupa "Ayo buat lihat itu contoh kalimatnya di depan". Perintah tersebut diberikan guru agar siswa mau bersemangat dan mau mengikuti perintah guru.

Pendekatan kekuasaan yang lain dilakukan guru ketika guru sedang menjelaskan pola kalimat ada siswa yang ribut, kemudian guru menegur siswa dengan berkata "Jangan ribut, dengarkan dulu ya”. Ketika guru memberikan contoh-contoh cara menggunakan pola kalimat ada siswa yang ribut, guru menegur dengan berkata "Tolong ya jangan ribut". Keributan siswa di kelas akan mengganggu proses pembelajaran. Guru menegur siswa untuk menghentikan keributan siswa sehingga siswa kembali tertib mengikuti kegiatan pembelajaran.

Selain itu ketika siswa sedang melakukan percakapan di depan kelas dengan pasangannya yang ditentukan sendiri oleh siswa ada siswa yang ribut, guru menghentikan keributan tersebut dengan cara menegur siswa dengan berkata "Jangan ribut, yang lainnya dengarkan", "Jangan ribut ya, dengarkan temannya di depan”. Dalam situasi demikian guru berusaha menghentikan keributan siswa agar siwa mau mendengarkan temannya yang melakukan percakapan di depan kelas. Karena semua siswa akan mendapat giliran untuk maju melakukan percakapan bersama pasangannya. Sehingga siswa kembali fokus mendengarkan temannya yang melakukan percakapan di depan kelas.

Pendekatan kekuasaan juga diberikan oleh guru ketika guru sudah selesai menjelaskan materi pelajaran, guru memberikan perintah dengan berkata "Silahkan dicatat". Guru akan memberikan kesempatan kepada siswa untuk mencatat materi yang sudah dijelaskan guru setelah diperintah guru. Dengan itu siswa akan tahu selama guru menjelaskan materi pelajaran siswa hanya fokus memperhatikan guru. Karena dalam hal ini guru mempunyai otoritas untuk mengatur kegiatan pembelajaran sehingga proses pembelajaran menjadi tertib dan terarah.

Berdasakan penjelasan yang dipaparkan sebelumnya dapat disimpulkan bahwa guru mendisiplinkan atau mengatur tingkah laku siswa dengan melakukan pendekatan kekuasaan. Selain itu guru melakukan pendekatan kekuasaan untuk menciptakan pembelajaran yang PAKEM yaitu salah satunya pembelajaran efektif. Pembelajaran efektif akan didukung oleh suasana pembelajaran yang kondusif dan terarah. Sehingga pendekatan kekuasaan yang dilakukan guru yaitu dengan mendisiplinkan dan mengatur tingkah laku siswa akan dapat membantu guru menciptakan pembelajaran efektif.

Pendekatan kebebasan yang dilakukan guru yakni guru memberikan kebebasan kepada siswa untuk mengembangkan ide dan wawasan tentang segala sesuatu. Contoh tindakan: ketika guru sudah selesai menjelaskan contoh kalimat, guru memberikan kesempatan kepada siswa untuk membuat percakapan dengan pasangannya kemudian tampil di depan kelas. Ketika guru sudah selesai menjelaskan kosakata, guru memberikan kesempatan kepada siswa untuk menyebutkan tempat wisata yang ada di Bali. Ketika guru sudah selesai menjelaskan pola kalimat, guru memberikan kesempatan kepada siswa untuk 
membuat contoh kalimat. Ketika guru sudah selesai menjelaskan kosakata, guru memberikan kesempatan kepada siswa untuk menyebutkan nama-nama hewan dalam bahasa Jepang. Ketika guru sudah selesai menyampaikan tujuan pembelajaran, guru memberikan kesempatan kepada siswa untuk berdiskusi mengenai hobi yang dimiliki masing-masing siswa.

Sehingga dapat disimpulkan bahwa pendekatan kebebasan yang dilakukan guru adalah memberi kebebasan kepada siswa untuk mengembangkan ide dan wawasan siswa tentang segala sesuatu. Hal itu akan memotivasi siswa untuk menghasilkan sesuatu ataupun melakukan sesuatu baik itu karya atau ide yang baru. Selain itu pendekatan kebebasan yang dilakukan guru akan membantu guru menciptakan pembelajaran PAKEM yaitu pembelajaran kreatif.

Pendekatan pengajaran dilakukan guru dengan merencanakan dan mempersiapkan pembelajaran dengan baik dengan itu tingkah laku siswa yang kurang baik dapat dicegah. Berdasarkan hasil observasi yang dilakukan sebelum guru melaksanakan pembelajaran di kelas guru sudah merencanakan pembelajaran melalui RPP yang disusun guru dengan baik. RPP tersebut dijadikan sebagai pedoman untuk guru melaksanakan pembelajaran di kelas dan dalam mengimplementasikannya ke dalam kegiatan pembelajaran guru menyesuaikan dengan kebutuhan dan kemampuan siswa di kelas.

Berdasarkan hasil wawancara Guru menyampaikan bahwa sebelum mengajar guru menyusun dan menyiapkan Rancangan Pelaksanaan Pembelajaran (RPP). Walaupun demikian dalam pelaksanaannya komponen-komponen yang ditulis di RPP disesuaikan dengan kondisi yang terjadi di kelas. Kegiatan pembelajaran yang tersusun dengan baik akan membantu dan memudahkan guru untuk melaksanakan pembelajaran di kelas, serta pembelajaran di kelas juga akan menjadi terarah.

Selain itu sebelum guru melaksanakan pembelajaran di kelas guru menyiapkan bahan ajar. Bahan ajar yang disiapkan guru berpedoman pada buku pelajaran Bahasa Jepang Sakura 2 dan Tanoshii Nihongo 2. Bahan ajar dan materi pelajaran sangat penting bagi siswa karena merupakan salah satu penunjang jalannya proses belajar mengajar. Guru perlu menyiapkan materi pelajaran agar tidak membingungkan guru ketika mengajar di depan kelas dan memudahkan siswa menerima serta memahami pelajaran yang disampaikan guru. Dengan adanya perencanaan yang baik dan persiapan yang baik dari guru munculnya tingkah laku siswa yang kurang baik dapat diatasi dan dicegah oleh guru.

Pendekatan perubahan tingkah laku yang dilakukan guru, untuk mengembangkan tingkah laku siswa yang baik guru memberikan penguatan positif dan untuk mencegah tingkah laku yang kurang baik guru memberikan penguatan negatif. Penguatan positif diberikan ketika ada siswa yang salah menulis huruf Hiragana, guru memberikan penguatan positif dengan berkata "lya tidak apa-apa salah, nanti belajar lagi ya di rumah". Kemudian guru memberitahu tulisan yang benar. Selain itu ketika siswa dapat menunjukkan lokasi suatu tempat yang diminta guru pada denah yang terdapat di papan tulis, guru memberikan penguatan positif dengan berkata "lya sudah betul ya". Ketika ada siswa yang menyebutkan hobinya melukis, guru berkata "Bagus ya".

Sedangkan untuk mencegah tingkah laku yang kurang baik, guru memberikan penguatan negatif. Ketika ada siswa yang duduknya menghadap ke samping, guru memberikan pengutan negatif dengan berkata "Jangan menghadap ke samping, silahkan menghadap ke depan". Ketika ada siswa yang mengganggu temannya belajar, guru memberikan penguatan negatif dengan berkata "Jangan diganggu temannya".

Pendekatan Suasana Emosi dan Hubungan Sosial, guru menciptakan iklim atau suasana emosi dan hubungan sosial yang positif di dalam kelas. Contoh tindakan yang dilakukan guru yaitu ketika guru sudah selesai menjelaskan materi pelajaran, guru bertanya 
kepada siswa dengan berkata "Apakah ada yang ingin ditanyakan?". Dalam hal ini guru bersikap terbuka kepada siswa. Sehingga siswa tidak akan merasa canggung ketika ingin bertanya kepada guru.

Ketika ada siswa yang tidur di kelas, guru berusaha tidak menunjukkan sikap marah dihadapan siswa. Melainkan guru mendekati dan mebangunkan siswa yang tidur tersebut. Kemudian guru berkata "Ayo perhatikan kembali". Dalam hal ini guru berusaha mengerti keadaan siswa yang pada saat itu sedang mengantuk. Guru berusaha sabar dalam mengatasi keadaan yang terjadi di kelas. Dengan adanya pengertian dari guru kepada siswa akan menciptakan hubungan yang baik antara guru dan siswa.

Selain menunjukkan sikap sabar guru juga menunjukkan sikap perduli terhadap kesulitan yang dihadapi siswa. Sikap tersebut ditunjukkan ketika ada siswa yang kesulitan menulis huruf Hiragana, guru mendekati dan membantu siswa. Dalam hal ini guru berusaha menjalankan tugasnya dengan baik. Karena tugas guru tidak hanya mengajar tetapi juga membantu kesulitan yang dihadapi siswa

Selain membantu siswa yang kesulitan menulis huruf Hiragana guru juga menunjukkan sikap kepeduliaannya ketika ada siswa yang tidak membawa pulpen, guru meminjamkan pulpennya kepada siswa. Pendekatan suasana emosi dan hubungan sosial yang dilakukan guru ditunjukkan guru melalui keterbukaan, pengertian dan kepedulian guru terhadap siswanya. Sikap-sikap yang ditunjukkan guru tersebut akan membantu guru menciptakan hubungan yang harmonis antara guru dan siswa.

Pendekatan Elektis atau Pluralistik guru memilih berbagai pendekatan berdasarkan situasi yang dihadapinya. Adapun pendekatan-pendekatan sudah dipaparkan pada pembahasan pendekatan pengelolaan kelas sebelumnya antara lain, pendekatan kekuasaan, pendekatan kebebasan, pendekatan pengajaran, pendekatan perubahan tingkah laku, serta pendekatan suasana emosi dan hubungan sosial.

Dalam proses pembelajaran untuk mendisiplinkan atau mengatur tingkah laku siswa guru menggunakan pendekatan kekuasaan dan pendekatan perubahan tingkah laku. Untuk membebaskan siswa mengembangkan ide dan wawasan siswa tentang segala sesuatu guru menggunakan pendekatan kebebasan dengan memberikan kebebasan kepada siswa dalam membuat contoh kalimat, membuat percakapan dengan pasangannya yang ditentukan sendiri oleh siswa dan berdiskusi mengenai hobi yang dimilki masing-masing siswa. Dalam menciptakan iklim atau suasana emosi dan hubungan sosial yang positif guru bersikap terbuka, sabar, mengerti, dan perduli terhadap kesulitan anak didiknya.

Selain menggunakan salah satu pendekatan pada situasi tertentu, guru juga menggabungkan beberapa pendekatan tersebut. Seperti ketika ada siswa yang tidur di kelas guru berusaha tidak menunjukkan sikap marah melainkan mendekati dan membangunkan siswa. Kemudian guru berkata "Ayo perhatikan kembali". Guru berusaha sabar saat menghadapi prilaku siswa yang kurang baik. Guru juga tetap menggunakan otoritasnya untuk kembali mendisiplinkan siswa. Dalam hal ini guru menggabungkan pendekatan suasana emosi dan hubungan sosial serta pendekatan kekuasaan.

Selanjutnya guru juga menerapkan prinsip-prinsip pengelolaan kelas. Pada prinsip hangat dan antusias guru menunjukkan sikap hangat dan akrab dengan anak didik dan guru selalu antusias dalam melaksanakan tugas-tugasnya. Kehangatan guru dalam mengajar terlihat ketika guru tersenyum dan menunjukkan keakraban dengan siswa. Contoh tindakan: Guru tersenyum ketika bertanya kepada siswa, guru tersenyum ketika mengkonfirmasi jawaban siswa yang ditulis di papan tulis, guru tersenyum ketika melihat siswa sedang mencatat.

Guru memberikan senyuman kepada siswa untuk memberikan kesan yang positif bagi siswa. Sehingga siswa tidak tegang dan santai saat mengikuti kegiatan pembelajaran. Selain 
itu dapat menciptakan pembelajaran PAKEM yaitu pembelajaran yang menyenangkan bagi siswa. Guru juga menunjukkan keakraban dengan siswa ketika siswa membuat contoh kalimat, guru mengajak siswa mengobrol dan membimbing siswa. Selain itu guru juga mendekati siswa dan mengajak siswa mengobrol ketika siswa sedang mencatat. Dalam hal ini guru berusaha menjalin komunikasi yang baik dengan siswa.

Keantusiasan guru dalam melaksanakan tugasnya dapat ditunjukkan guru, ketika guru memeriksa buku catatan siswa. Guru memastikan bahwa siswa sudah mencatat materi yang sudah diajarkan guru. Keantusiasan guru juga terlihat ketika guru berusaha membantu kesulitan yang dihadapi siswa.

Prinsip tantangan yang dilakukan guru, guru memberikan tantangan berupa pertanyaan-pertanyaan dan menggunakan kata-kata untuk meningkatkan gairah belajar siswa. Contoh tindakan: Setelah guru selesai menjelaskan materi pelajaran, guru memberikan pertanyaan kepada siswa dengan berkata "Minasan Mie Ayam wa oishii desuka?", "Minasan Bali wa donna tokoro desuka?", "Minasan gakkou wa doko ni arimasuka?", "Minasan donna kamoku ga suki desuka?". Pertanyaan-pertanyaan yang diberikan guru dalam bahasa Jepang adalah pertanyaan-pertanyaan yang berkaitan dengan materi pelajaran yang sudah dijelaskan guru. Dengan itu siswa berusaha berfikir untuk menjawab pertanyaan dari guru. Sehingga akan meningkatkan gairah siswa untuk belajar.

Selain itu guru juga memberikan tantangan berupa kata-kata yang diucapkan guru ketika guru menunjuk siswa untuk menjawab pertanyaan yang di berikan guru di papan tulis, guru berkata "Yang laki-laki belum ada yang maju, ayo sekarang yang laki-laki siapa yang mau maju menjawab?". Setelah mengucapkan kata-kata tersebut beberapa siswa laki-laki mengangkat tangannya sebagai tanda bersedia untuk menjawab pertanyaan yang diberikan.

Dalam hal ini guru berusaha melibatkan siswa dalam proses pembelajaran. Pada kegiatan pembelajaran study centre kegiatan pembelajaran tidak hanya didominasi oleh guru saja akan tetapi siswa juga harus ikut berperan di dalamnya. Oleh karena itu pada tantangan yang diberikan guru selain untuk menintkatkan gairah belajar siswa juga dapat membantu guru menciptakan pembelajaran PAKEM yaitu pembelajaran aktif dan Partisipatif.

Prinsip bervariasi yang dilakukan oleh guru dalam mengajar ditunjukkan dengan variasi suara, variasi gerakan anggota badan dan melakukan pergantian posisi. Adapun variasi suara yang dilakukan guru yaitu, guru menggunakan nada suara rendah ketika hal-hal yang semestinya dilakukan oleh siswa seperti mengintruksi siswa untuk mencatat materi pelajaran yang sudah dijelaskan guru, menggunakan nada suara rendah ketika menyuruh siswa untuk menyebutkan tempat wiasata yang ada di Bali. Guru menggunakan nada suara rendah ketika meminta siswa untuk membuat contoh kalimat. Guru menggunakan nada suara yang cukup keras untuk memusatkan perhatian siswa seperti ketika menegur siswa yang tidak memperhatikan guru, menggunakan nada suara yang cukup keras ketika menegur siswa yang mengganggu temannya belajar. Guru menggunakan nada suara tinggi ketika menekankan pada sesuatu hal untuk diperhatikan seperti ketika guru menunjuk siswa untuk menjawab pertanyaan yang diberikan guru.

Guru menggunakan variasi gerakan anggota badan. Ketika guru menjelaskan kosakata yang berkaitan dengan Shumi (Hobi), guru menjelaskannya dengan gerakan tubuh/badan. Hal tersebut dilakukan guru untuk menarik perhatian siswa untuk memperhatikan guru mengajar. Pandangan siswa akan terfokus kepada guru. Selain itu gaya mengajar yang dilakukan guru tersebut dapat membantu guru untuk menyampaikan pesan lisan yang dimaksudkan guru.

Selain menggunakan variasi gerakan anggota badan, guru melakukan pergantian posisi. Ketika mengajar guru melakukan pergantian posisi di dalam kelas. Ketika siswa mencatat dan membuat contoh kalimat guru berkeliling mengamati siswa, ketika siswa 
melakukan percakapan di depan kelas guru melakukan pergantian posisi dari tempat duduk kemudian guru mendekati siswa yang melakukan percakapan, ketika guru menjelaskan materi pelajaran guru melakukan pergantian posisi dari kanan ke kiri dan sebaliknya. Guru melakukan pergantian posisi agar tidak kaku/kikuk dan tidak berfokus pada satu tempat saja. Sehingga hal tersebut akan menarik perhatian siswa mengikuti kegiatan pembelajaran.

Prinsip penekanan pada hal-hal yang positif, guru memberikan penguatan yang positif, pujian, ataupun apresiasi ketika anak didik dapat melaksanakan tugasnya dengan baik. Contoh tindakan: ketika siswa memperlihatkan buku catatannya kepada guru, guru memberikan pujian dengan berkata "Catatan kamu sudah rapi". Selain itu ketika siswa dapat menunjukkan lokasi suatu tempat yang diminta guru pada denah yang terdapat di papan tulis, guru memberikan apresiasi dengan berkata "lya sudah betul ya". Ketika ada siswa yang menyebutkan hobinya melukis, guru memberikan pujian dengan berkata "Bagus ya". Pujian yang diberikan guru terhadap siswa tersebut menunjukkan dukungan guru terhadap hobi yang dimiliki siswa tersebut. Sehingga pemberian penekanan pada hal-hal yang positif pada siswa akan menghindari pemusatan perhatian anak didik pada hal-hal yang negatif.

Penanaman disiplin diri yang dilakukan guru, guru berdisiplin dalam segala hal dalam upaya mengembangkan disiplin diri pada siswa. Contoh tindakan: Ketika guru mengajar, guru berpenampilan yang rapi dan bersih di depan siswa. Selain itu ketika berkomunikasi dan menegur siswa yang tingkah lakunya kurang baik, guru menggunakan kata-kata yang sopan dan tidak kasar. Guru juga tepat waktu ketika memulai dan mengakhiri pembelajaran. Perilaku yang ditunjukkan guru merupakan bentuk perilaku disiplin guru yang dapat diteladani oleh siswa agar siswa dapat mengembangkan disiplin diri sendiri. Karena guru harus berdisiplin dalam segala hal agar siswa juga ikut berdisiplin dalam segala hal.

Selain pendekatan dalam pengelolaan kelas dan prinsip-prinsip pengelolaan kelas guru juga menerapkan komponen-komponen pengelolaan kelas. Pada komponen-komponen pengelolaan kelas dibagi menjadi dua bagian, yaitu keterampilan yang berhubungan dengan penciptaan dan pemeliharaan kondisi belajar yang optimal dan keterampilan yang berhubungan dengan pengembangan kondisi belajar yang optimal.

Dalam keterampilan yang berhubungan dengan penciptaan dan pemeliharaan kondisi belajar yang optimal terdapat sikap tanggap. Guru menunjukkan sikap tanggap terhadap segala aktivitas yang dilakukan siswa. Sikap ini dapat ditunjukkan oleh guru dengan cara guru melakukan kontak pandang dengan siswa, guru melakukan gerak mendekati, guru memberi reaksi terhadap masalah yang disampaikan oleh siswa.

Contoh tindakan: Guru melakukan kontak pandang dengan siswa ketika guru menjelaskan materi pelajaran, ketika siswa bertanya, ketika guru menjawab pertanyaan siswa, ketika guru meminta siswa untuk membuka buku catatan siswa, ketika menunjuk siswa untuk membuat contoh kalimat di papan tulis, ketika membantu siswa yang kesulitan menulis huruf Hiragana. Sikap tanggap gerak mendekati ketika guru memeriksa buka catatan siswa, ketika ada siswa yang tidur, ketika ada siswa yang kesulitan menulis huruf Hiragana, ketika ada siswa yang tidak membawa pulpen.

Sikap tanggap guru memberi reaksi terhadap masalah yang disampaikan oleh siswa ketika salah satu siswa menyampaikan bahwa ia lupa membawa buku catatannya, guru menanggapinya dengan berkata "Pertemuan selanjutnya ingat dibawa ya, nanti pinjam dulu catatan temannya".

Kemudian guru membagi perhatian, guru membagi perhatiannya secara visual dan verbal. Contoh tindakan: Membagi perhatian secara visual ditunjukkan guru ketika siswa membuat contoh kalimat di papan tulis, guru memusatkan perhatiannya kepada siswa tersebut. Kemudian guru mengalihkan pandangannya dengan melirik siswa yang bertanya kepada guru. 
Membagi perhatian secara visual lainnya ditunjukkan guru ketika guru meminta siswa menunjukkan lokasi suatu tempat pada denah yang terdapat di papan tulis, guru memusatkan perhatiannya kepada siswa tersebut. Kemudian guru mengalihkan pandangannya dengan melirik siswa yang ribut. Seketika suasana kelas hening.

Contoh tindakan verbal yaitu guru mengomentari siswa yang sedang menulis contoh kalimat di papan tulis dengan berkata "Tolong ya cara bacanya ditulis, biar tahu temantemannya", sementara guru sedang membantu siswa lain yang kesulitan membuat contoh kalimat.

Pada keterampilan yang berhubungan dengan pengembangan kondisi belajar yang optimal guru memodifikasi tingkah laku siswa. Modifikasi tingkah laku adalah upaya guru untuk mengubah tingkah laku siswa dengan memberikan penguatan secara sistematis. Dari yang telah dijelaskan sebelumnya pada pendekatan kekuasaan dan pendekatan perubahan tingkah laku. Guru memberikan penguatan positif dan penguatan negatif negatif. Misalnya ketika ada siswa yang ribut dan tidak memperhatikan guru, guru memberikan penguatan negatif berupa teguran. Pemberian penguatan negatif dengan maksud untuk menghilangkan tingkah laku siswa yang dianggap menggangu jalannya pembelajaran.

Sedangkan pengutan positif diberikan guru berupa pujian atau apresiasi kepada siswa, misalnya ketika siswa memperlihatkan buku catatannya kepada guru, guru memberikan pujian dengan berkata "Catatan kamu sudah rapi". Tujuan guru memberikan penguatan positif berupa respon positif atau dukungan yang diberikan kepada siswa agar siswa bisa mempertahankan perilakunya yang baik dan bisa melakukan hal yang lebih baik lagi.

\section{Simpulan dan Saran}

Kesimpulan dari hasil penelitian ini dapat dijabarkan sebagai berikut. Guru bahasa Jepang di kelas XI IPB SMA Wirabhakti Singaraja melakukan pengelolaan kelas dengan baik. Pengelolaan kelas yang dilakukan guru dibuktikan dengan menerapkan pendekatanpendekatan pengelolaan kelas, prinsip-prinsip pengelolaan kelas, dan komponen-komponen pengelolaan kelas.

Dalam pendekatan pengelolaan kelas guru menerapkan pendekatan kekuasaan, pendekatan ancaman, pendekatan kebebasan, pendekatan pengajaran, pendekatan perubahan tingkah laku, pendekatan suasana emosi dan hubungan sosial dan pendekatan elektis atau pluralistik. Guru juga menerapkan prinsip-prinsip pengelolaan kelas diantaranya sikap hangat dan antusias, tantangan, bervariasi, penekanan pada hal-hal yang positif, dan penanaman disiplin diri.

Selain pendekatan pengelolaan kelas dan prinsip pengelolaan kelas guru menerapkan komponen-komponen pengelolaan kelas. Komponen komponen pengelolaan kelas dibagi menjadi dua bagian, yaitu keterampilan yang berhubungan dengan penciptaan dan pemeliharaan kondisi belajar yang optimal dan keterampilan yang berhubungan dengan pengembangan kondisi belajar yang optimal. Pada bagian keterampilan yang berhubungan dengan penciptaan dan pemeliharaan kondisi belajar yang optimal meliputi sikap tanggap, membagi perhatian. Sedangkan keterampilan yang berhubungan dengan pengembangan kondisi belajar yang optimal hanya meliputi modifikasi tingkah laku.

Pengelolaan kelas yang dilakukan guru untuk menciptakan pembelajaran PAKEM yaitu dapat ditemukan pada pendekatan kekuasaan untuk menciptakan pembelajaran efektif, pendekatan kebebasan untuk menciptakan pembelajaran kreatif, prinsip hangat dan antusias untuk menciptakan pembelajaran menyenangkan dan prinsip tantangan untuk menciptakan Jurnal Pendidikan Bahasa Jepang | 354 
pembelajaran partisipatif dan aktif. Sehingga pengelolaan kelas yang dilakukan guru sebagai upaya guru untuk menciptakan pembelajaran PAKEM yaitu pembelajaran partisipatif, aktif, kreatif, efektif, dan menyenankan.

Berdasarkan temuan dalam penelitian ini, berikut ini akan disampaikan beberapa saran. Bagi Guru, peneliti memberi saran kepada guru, diharapkan kedepannya dapat meningkatkan keterampilannya khususnya dalam mengelola kelas. Selain itu guru seharusnya memanfaatkan media gambar dalam menjelaskan materi pelajaran agar siswa lebih tertarik dan tidak merasa bosan atau jenuh ketika mengikuti kegiatan pembelajaran. Bagi Siswa, seharusnya siswa lebih meningkatkan kedisiplinannya baik dalam menjaga kerapian dan menjaga tingkah lakunya di kelas. Selain itu siswa lebih mengembangkan potensi dirinya sehingga akan membantu guru mencapai tujuan pelajaran yang diharapkan.

\section{DAFTAR PUSTAKA}

Djamarah, Syaiful Bahri dan Aswan Zain. 2006. Strategi Belajar Mengajar. Jakarta: PT Rineka Cipta.

Riadi, Riyan. 2018. "Pengelolaan Kelas Dalam Pembelajaran Bahasa Jepang Oleh Guru Bahasa Jepang SMA Negeri 2 Singaraja". Tersedia pada https://ejournal.undiksha.ac.id/index.php/JJPBJ/article/view/14953 (diakses pada tanggal 7 April 2019)

Rohani, Ahmad. 2004. Pengelolaan Pengajaran. Jakarta: Rineka Cipta

Sani, Abdullah. 2019. Strategi Belajar Mengajar. Depok: Rajawali Pers.

Sumantri, Mulyani dan Johan Permana. 1998. Strategi Belajar Mengajar. Jakarta: Departemen Pendidikan dan Kebudayaan.

Undang-Undang Republik Indonesia no. 14 Tahun 2005 tentang Guru dan 